\title{
SNAPSHOTS THEN AND NOW: FEMINISM AND THE LAW IN ALBERTA
}

\section{ANNALISE ACORN ${ }^{*}$}

The pioneering efforts of women such as Emily Murphy in Alberta during the early part of this century effected legal change and altered women's lives. Women began to see the law as a vehicle for social change, entilling them to property and giving rise to new expectations that a world of "true happiness" would emerge.

However, this time also saw the beginnings of fractures and divisions in the modern feminist movement based on race, class and sexual orientation. Late twentieth century feminist theory has, in part, been an attempt to overcome theoretical imperatives of universalism (the nature of mankind) and essentialism (features common to all women), with mixed results. Nonetheless, the failures of feminists in this area who have acted at cross-purposes do not erase the successes in the same project and the influence felt at the University of Alberta.
Les efforts audacieux de certaines pionnières telles que Emily Murphy en Alberta au début du siècle ont fait évoluer les lois et transformé la condition féminine. Les femmes ont commencé à percevoir la Loi comme un outil de changement social leur donnant droit à la propriété et porteur d'un monde de "réel bonheur".

Mais cette époque a également donné lieu à des fractures et des divisions fondées sur la race, la classe et l'orientation sexuelle dans le mouvement féministe moderne. La théorie féministe de la fin du $X X$ siècle s'efforce en partie de surmonter les impératifs de l'universalisme la nature de l'humanité) et de l'essentialisme (les caractéristiques communes à toutes les femmes) avec un succès mitigé. Mais les échecs des féministes agissant $\dot{a}$ contre courant dans ce domaine n'effacent pas les progrès réalisés ni l'influence ressentie à l'Université de l'Alberta.

\section{TABLE OF CONTENTS}

I. LOOKING AT OLD PHOTOS:

EMILY THE WISE AND POWERFUL $\ldots \ldots \ldots \ldots \ldots \ldots 142$

II. LATE TWENTIETH CENTURY FEMINIST

THEORY: A SCRAPBOOK OF THE STRUGGLE

AGAINST UNIVERSALISM $\ldots \ldots \ldots \ldots \ldots \ldots \ldots \ldots \ldots$

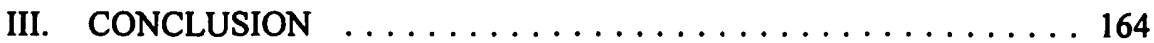

I like to think of this article as two photo albums. The first album, captured at the moment of the opening of the University of Alberta Faculty of Law, is a collection of pictures of Edmonton's Emily Murphy and the diverse lot of women she was surrounded by. In tones of sepia, this scrapbook is full of glimpses of practical truth, of every day reality, plain speaking exercises of power and experiences of pain. It is a voyeur's assortment of stolen shots of Emily Murphy, immersed confidently and unselfconsciously in her work in the 1920s as the first woman police magistrate in the British Empire. In this album we see the beginnings of a heady optimism about the transformative power of the law in women's lives. Here Emily Murphy's letters provide some fascinating insights into the lives of women struggling with their relationship to the law on the Alberta prairies at the beginning of this century. In some moments we see Mrs. Murphy as a messiah of women's emancipation wielding the power of the law in women's interests and holding the promise of deliverance from misery and oppression - a wise and powerful goddess of both discipline and compassion. Other 
pictures do not show such a flattering likeness and, rather, reveal her as sanctimonious and bigoted, harbouring a hoard of small minded hostilities toward women who deviated from the normative prescriptions of hard working, hetero, white, anglo, wellbehaved, well groomed, well balanced, well-heeled, good girl, Christian, womanhood.

It is of course, not surprising that Murphy's exercise of power would have been informed by an elitist perspective. Murphy was a leading member of prairie society, she was a well known and well loved author of fiction with her immortal character "Janey Canuck" and she was also an outspoken commentator in the Canadian newspaper and magazine media. She was a highly influential and well connected member of the Western Canadian community. Her work and her writing reveal a woman with an unshakable sense of the entitlement of her class to rule over those who were less competent and less worthy. Murphy's adherence to eugenics and her anti-semitism have caused a great deal of controversy around the issue of her status as a prairie heroine. She has received as much derision as acclaim; and both have been well deserved.

I want, then, to draw first on the tableaus found in Emily Murphy's letters to demonstrate Murphy's power and commitment as well as her shortcomings as a leader in the women's movement. Her letters are useful in that they give us graphic depictions both of the way in which law and legal rules were the primary modalities through which women understood and articulated their oppression. Further the letters demonstrate that it was via the envisioning of change to legal rules that women imagined the details of their incipient freedom. By exhibiting these letters I also want to show the way in which Murphy fell into the kind of insensitivity and arrogance that later feminists have denounced and struggled to transcend. I want to show how Murphy was fighting, on the one hand, for women but, on the other hand, was operating with an understanding of "woman" that was oppressive to women who did not conform to its expectations. Thus, the first half of the discussion demonstrates how Murphy's orthodoxy about who was to count as a woman, could not possibly be anything other than exclusionary and cruel toward women who did not conform to the privileged understanding of the "woman worth fighting for" or the woman on whose behalf women should be liberated.

I want to suggest further, that Murphy's ruthlessness and insensitivity bespeaks a theoretical failure linked to the concepts of universalism and essentialism. When I speak of essentialism here I mean the practice of positing certain characteristics as being fundamental to, or constitutive of, womanhood. When I speak of universalism I mean the practice of assuming that conclusions drawn from one's own experience can be extended to apply to others. Murphy's essential characteristics of worthy womanhood emerge through her letters as: heterosexuality, an able body, white skin, traditional motherhood, mental stability, and sexual conformity - to name a few. For Murphy, those women who exist beyond the lines drawn by these standards are undeserving. Further, Murphy universalizes her own understanding of the world with a staggering confidence.

The second album is very different from the first. It is both modern and abstract. It too contains images of women struggling to change the world. But it is more about 
their ideas than it than it is about the concrete circumstances of their lives. It contains a number of portraits of late twentieth century feminist theorists. It is a picture book of women whose influence in the law school at the University of Alberta has shaped many Alberta lawyers' and scholars' thoughts about the relationship between gender and the law. The images in this second album come long after the pioneering efforts of Mrs. Murphy. However, the second album is not unrelated to the first. The second album builds on the vigour of the first. It takes its inspiration and its bravado from the first. But its conflicts and its places of acute tension and struggle can be traced back to the short comings of the images we see in the first album. The second album shows the struggle of late twentieth century legal feminism to transcend the universalist, essentialist, classist, racist, homophobic - in an unwelcome word - the chauvinistic quality of its beginnings.

Thus, in the second half of the discussion I want to depict the way in which these debilitating moral blind spots of women like Murphy have persisted as problems in feminist theory well into the late twentieth century. Late twentieth century legal feminists still grapple with the problem of how to participate in the legal system while righting the wrongs of white heterosexual bourgeois women of privilege in their essentialist and universalist understandings of womanhood. Thus, the first half of the paper demonstrates the difficulties of essentialism and universalism as they are practiced by Murphy. The second half of the article attempts to show various strategies feminists have employed to overcome these failures while retaining the notion of "woman" as a coherent and real political and moral category.

\section{LOOKING AT OLD PHOTOS: EMILY THE WISE AND POWERFUL}

In the 1920s Alberta could boast a colourful cast of strong, outspoken women wielding legal skill and political power. When Lord Sankey of the Judicial Committee of the Privy Council in England began his judgment in Edwards v. A.G. Canada by reviewing the impressive civic credentials of the five Alberta women appellants in the case, there could be no doubt that he was about to overturn the judgment of the Supreme Court of Canada rendered in $1928^{2}$ holding that women were not included in the meaning of "persons" in s. 24 of the British North America Act, 1867. Lord Sankey's opening statement in deciding the case was this:

Of the appellants, Henrietta Muir Edwards is the Vice-President for the Province of Alberta of the National Council of Women for Canada; Nellie L. McClung and Louise C. McKinney were for several years members of the Legislative Assembly of the said Province; Emily F. Murphy is a police magistrate in and for the said Province; and Irene Parlby is a member of the Legislative Assembly of the said province and a member of the Executive Council thereof. ${ }^{3}$ 
How could he, a man defined by his public accomplishments, have gone on from there to decide that these impressive public figures were not persons?

Many prairie women of Alberta took hold of the hope held out by these formidable leaders. Indeed, their faith in the promise of law reform to eliminate inequalities for women seems to have taken on an almost spiritual quality. The idea that women's oppression could be obliterated by changes in the law, particularly changes that altered a woman's entitlement to property, was strong and gave rise to great expectations and inspired energetic enthusiasm in women who wanted things to be different. One woman expressed such a sentiment writing to Emily Murphy thanking her for sending some information. She wrote:

Chauvin Dec. 27-24

Mrs. E Murphy

Magistrate of Juvenile Court

Edmonton

I am taking the liberty of addressing a few words of thanks to you for sending me the information which I desired.

Further, I would like to tell you what no doubt hundreds of other women of Alberta has already told you, that you cannot conceive the great joy and blessing and up-lifting of heart and spirit it gives and will give to women to see some of the old laws concerning our sex, smashed to pieces, and to see laws of justice taking their place, and we can thank our brave women of Alberta who have stepped forward into public life, which in time past was known only to man, hence the selfish manmade laws. Community of interest between husband and wife, the better care of the poor innocent illegitimate child, and the mentally defectives cannot help but be recognized as true justice to humanity.

My heart aches for some poor brow-beaten wives, I tell you if these poor creatures had as much legal rights to the home property as their husbands, those very same husbands would be very much more considerate to their wives and their poor wives would not be looking old enough to be their husband's mother or perhaps grandmother. I know of a few cases and oh! so many many there are that I don't know of.

I must not take up your time reading a long letter for you no doubt have many such a day. So will just say God Speed you in your good work.

\section{Yours Sincerely}

Mrs. L.A. Cayford

Chauvin Alberta ${ }^{4}$

The belief that changes in women's entitlement to property in a marriage would alter the relation of domination and subordination between husband and wife is echoed in the following letter also written to Emily Murphy by a prairie farmer - a woman who clearly would not have called herself a farmer and yet the injustice of the exploitation 
of her labour on the farm fuels the passionate eloquence of her supportive words to Emily Murphy. Her voice is resounding with desire for acknowledgement of her contribution and toil on the farm. She writes with a stinging sense of the injustice of having been deprived of her status as a woman because she was a farmer and being deprived of her status of a farmer because she was a woman. Yet her words disclose a belief that somehow new laws could bring together - could reconcile these two quite disparate existential states. She writes:

\section{Dear Madam,}

Seeing the notice in the Free Press re Dower Law for Alberta, I think it is time we did have such a law. I don't understand quite what the Dower Law is. But thinking that it is a Law giving Married women a lawful right to half of everything that her husband owns lands houses and moveable property of all kinds, is that so?

My husband has all along let me understand that $1 / 3$ of his estate goes to the wife and $2 / 3$ to his children at his death but now I am convinced that I might get nothing and that he might give his all away from me and my young family of seven.

I must say that he has threatened to do so whenever any little thing crosses him, now I left all my friends, and comforts and society and came to this new country and had many lonely trying times, endured many hardships including hunger and cold. Have had to do all kinds of work out door in all kinds of weather, chop wood, carry water, milk cows, feed horses and cattle, feed pigs etc. etc.all sorts of work that a hired man would have to do besides all the baking cooking washing and housework for a large family and without the modern convenience of labour saving machinery also most all my children's clothes I make beside most of my own and my husbands. My husband owns half a section of good land and hires no help. I help in the haying and harvest plant along with my children (the oldest is only 10 years old) more than an acre of potatoes which we all gather in the fall and let my husband plough. I do all that and lots more which I know most women around me would not dream of doing. I am seldom from home, never get to church or party no pleasure or company of any kind so the reason I could not invite anyone to come and spend an afternoon. I am always kept so full of work and my house though large has no furniture of any kind but a stove table and chair only two. I have not even a rocker or a cay chair to set down and rest my weary body and tired back. I have nothing but the bare necessities of life. If I thought that I had to live my life out like this I think I would go crazy but I have great hopes and that with my trust in God keeps me going. But it would be a great comfort and security for most women to be assured that if her husband died something would be hers to start with especially a woman who helps her husband.

My husband is always crying that I never help him enough, and yet I raise lots of chickens, ducks and turkeys for him to sell, the profits of which I never get. I never get 5 cents to spend as I like I must account for every cent he gives me for provisions etc.

I think if a wife got one half of all her husbands property and everything belonging to him it would be only her due and little at that and if the other half went to the children they would only get it when they come of age and many young folks would only spend it foolishly while if it could be spent on their education that would help greatly... I really think that if we women had a Law compelling men to go equal shares with their wives there would be more home comforts and true 
happiness, less bachelors less race suicide, as wives would not fear having to provide and educate their children if left with a big family. Shame on the Farmers of Western Canada. They cry for Equity Associations, Good, Honesty. But how few of them would ever think of being Even and Equal with the wife of his bosom.

\section{A Western Canadian Wifes}

Women's faith in the law as a transformative tool for bringing about social equality and even harmony between men and women seems to have been unwavering and their faith in compelling heroines of the law such as Emily Murphy appears to have been equally steadfast. Their words betray a belief that changes in the law could bring about a utopian future where women's work in the home was no longer unpaid and unacknowledged, where husbands were considerate of wives, where children's needs for support and education were provided for: in short - a belief that the law could play a significant role in taking us closer to a world of "true happiness."

Mrs. Murphy's confidence in the law, ease, comfort, and exuberance in the exercise of her legal power is both impressive and slightly unsettling. Perusal of her letters clearly reveals that she was struggling from the margin to maintain her position within institutions of legal power and was simultaneously exercising that coercive power from a place of solid entitlement. Thus, her compassion is sometimes matched with arrogance and an utter absence of tentativeness. Of course, given the opposition to her presence on the court, one can well imagine that humility was not a luxury that her circumstances could afford her. ${ }^{6}$ One glimpse at a crack in her resolve and assuredness might have been all that was needed by her opponents to succeed in demolishing the fragile edifice of her authority. And so, it may be the case that she was pushed by predators, hungry for her demise, into a place of inability to exercise the humility that must surely be the hallmark of any truly wise judge. Nevertheless, Emily Murphy's papers reveal as much rigid and unfeeling bigotry as they do right-headed humanity.

Thus, in the papers of Emily Murphy chronicling this daring experiment in the construction of authority, we can see the beginnings of the bitter fractures of the feminist movement. Divisions on grounds of difference - race, class, and sexual orientation have since plagued the feminist movement and have given rise to the acrimonious defrocking of many a feminist heroine. Murphy's hostility or indifference to women seen by her as "other" is repeatedly revealed in the substance of her papers.

Edmonton City Archives, MS2 Emily Ferguson Murphy Collection, Box 1, File 1 [emphasis in the original].

- See John McLaren, "Maternal Feminism in Action - Emily Murphy, Police Magistrate" (1988) 8 Windsor Yearbook of Access to Justice 234 at 237 where McLaren discusses the numerous and vicious challenges to Murphy's authority. He writes:

Antipathy towards her was not limited to law enforcers and civil servants. Occasionally she ran into hostility and rudeness from lawyers. In $R$ v. Nora Holt in 1917, Eardley Jackson, representing the accused, who had been sentenced by Magistrate Murphy to a $\$ 50.00$ fine and two months in jail for being unlawfully in possession of a loaded pistol, was heard to remark, "To hell with Women Magistrates, this country is going to the dogs because of them. I would commit suicide before I would pass a sentence like that" 
She emerges as the quintessential white heterosexual woman of privilege using institutional power to advance the cause of women like herself and to define the women's movement in accordance with her own narrow set of interests.

Murphy's homophobia is clearly revealed in an almost amusing document entitled: Evidence taken under oath given by Ellen McKenzie, this 29 th Day of July, 1920 before Mrs. Emily Murphy, Police Magistrate, in regard to conditions at the Fort Saskatchewan Gaol which reads as follows:

Q. The conditions at the gaol are reported to be very bad among the women. I am not laying a charge against you at all, but I hear the women are doing unnatural practices there?

A. That is what I heard, I never seen it.

Q. Who told you about it?

A. They accused a girl there. Agnes Colburt and Ruth Cody for doing wrong things with other women. A bunch of dirty women down there.

Q. Can they get a chance to get in bed together down there?

A. They are not supposed to do it, but they do it. Hazel Ritchie was not supposed to have gonorrhea but now she has it. They get it from the other girls that is what they say.

Q. Did you ever see them?

A. I have never seen nothing wrong with the girls. I have seen them sleep together, girls are not supposed to sleep together.

Q. What other girls did you see sleep together?

A. They lay on one another's bed.?

Here Murphy pursues a line of questioning without any solid legal foundation for her interest in the matter and in the face of clear indications that the woman whom she was cross examining did not have any personal knowledge of the sexual conduct in question. Her contemptuous narration of lesbian sexuality as unnatural is enough to make any modern feminist cringe and her use of her legal power to presumably to persecute and punish lesbian practice is scandalous by today's standards of feminist thought.

Another of Murphy's sinister attitudes - her adherence to eugenics - is evident in her sentencing of a couple, Hariet MacDougal and William Ciples, for the offence of 
being "wilfully guilty of an act producing promoting or contributing to Donald and Margaret McDougall being or becoming neglected children contra to the Children's Protection Act of Alberta." 8 It becomes clear in the course of Murphy's comments on sentencing that her primary hostility arises out of her disdain for the parents' choice to have children when the father had epilepsy. Her judgmental attitude toward these parents, fuelled by her belief that the betterment of the world was contingent on the elimination of "defectives," " seems to have inspired a particularly retributive mood in Mrs. Murphy on that April 17, 1919. Further, her breathtaking ability to haughtily label those before her as "no good" 10 inspires, yet more wincing in the modern feminist sensibility. Her willingness to blame the mother for the faults of the children is also of interest since it gives us insight into the incentive a woman must have had at that time to try to control her children lest she be condemned for their failings. The transcript reads as follows:

17th April, 1919

Mrs. McDougall and Wm. Herbert Ciples called and sworn Mrs. McDougall how do you plead to this?

A. Guilty

Mr. Ciples how do you plead?

A. Guilty

Magistrate

Mrs. McDougall I do not consider that any woman in this city has got more help from every institution than you have, everyone has given you a helping hand and from time to time I have heard stories about you and I have shut my ears, and I think you are no good. Every one of your children except those that have been taken away from you have turned out badly. These children are not going to be left with you they are to be taken away. Moreover, if it were not for your lawyer Mr. Marks I would send you to jail, you have done a great wrong to your family and you are no good, and I think the worst thing you have done is to bring a child into the world probably to become an epileptic like its father. I shall sentence you to two months in Fort Saskatchewan jail, sentence to be suspended for one year.

Mr. Ciples

Q. What work have you been doing?

A. I am a labourer, I do work whenever I can get it to do, and my health will permit me, I can bring witnesses to show you that, as regards my character I have lived in

- Edmonton City Archives, MS3 Emily Ferguson Murphy Collection, Box 1, File 10.

, Ibid.

10 Ibid. 
the city here for a number of years. I met the lady here some years ago and when she asked me to help her I did help her.

Q. How often do you have these fits?

A. I had one the 25th, March, they were caused in the first place by an accident, and they are growing less frequent all the time, and I wish to say Mrs. McDougall has tried to help herself all she could. She is not a slacker.

Magistrate:

You have no business having children in your condition. And I am going to sentence you to one month in Fort Sask. jail sentence to be suspended for one year, and you must provide for this last baby.

I make the other children wards of the Department. I do not wish them left with Mrs. McDougall, I wish them taken out of this home and otherwise disposed of."

Murphy's judgmental tone in relation to the evil of someone with epilepsy having children is all the more fatuous given that Mr. Ciples' seizures, if occurring as a result of a head injury as his testimony suggests, would most likely not be related to his genetic make-up and could not have been passed on to his children in any event. In any case her hostility to physical disability is breathtaking by today's standards.

It is also clear from Murphy's papers that women looked to her as an enforcer of conventional sexual morality. Far from pursuing a feminist project of releasing women from the oppression of compulsory heterosexuality and marriage, Emily Murphy seemed keen to embrace her position of authority as an opportunity to dispense a stern womanly chastisement to those who ventured outside the boundaries of orthodox sexual confinement in the traditional family. Women's responsibility for maintaining the boundaries of traditional sexuality would seem to have had two aspects. First, it was women of power and "good breeding"12 such as Mrs. Murphy who were seen to be the best suited to patrol those boundaries. Second, it was also the case that when boundaries were transgressed it was usually seen to be the fault of a woman who had gone wantonly astray and had lead otherwise innocent men in the same direction. One intriguing letter to Mrs. Murphy reads:

25-21st St. West, Prince Albert Sask.

June 17,1916

Mrs. Arthur Murphy,

Edmonton, Alberta

11 Ibid

12 Edmonton City Archives, MS2 Emily Ferguson Murphy Collection, Box 1, File 4. 
Dear Mrs. Murphy:

I am very happy to learn of your appointment to the position of Police Magistrate. We have needed a woman in that position for a long time, and I know of no other woman in public life in the city, that would be more capable and more conscientious than yourself to fill this position, and the people of Edmonton are very fortunate in being able to secure your services.

I have a matter which I would like to call your attention to, and you can do what you deem best.

There is a man and young woman who I think are at present registered at one of the local Hotels as H. V. Dardier and wife. This Dardier has a crew of about 100 men in at Fond Du Lac, some 300 miles north of Fort McMurray, working the silver claims. He went in last Sept. with this woman and came out about two weeks ago, intending to return very soon. My husband Mr. Twitchell is at Pelican, and these people stopped there on their way up river, and he told me about how they were all drunk and how this woman lived with all the men.

Now I contend that a woman of that kind should not be allowed in that far North country, as you know yourself what damage a white woman can do among a bunch of white men in the far north, where otherwise if they were not allowed to go up there, these men might live decently and be true to those they have left outside.

I think Mrs. J. K. Cornwall is acquainted with or knows of this woman, as she Mrs. Cornwall was at Athabasca last Sept. when these people started down river.

Although I am out of the city this summer, I am interested in anything pertaining to the welfare of the city or district.

If you do not remember me, call up Mrs. Clyde MacDonald and she will tell you who I am.

I do not know that anything can be done in this matter but I wanted to bring it before you, as I feel that these fast white women should be kept (as far as possible) out of that far north country.

I was at Pelican when these people went into the north in Sept. 1915, and this woman was common talk at that time, but I did not believe that she was not his wife.

Trusting you will do as you deem best in this matter and With best wishes for the success of your work, I remain.

Very truly yours,

Mrs. W. B. Twitchell ${ }^{13}$

The issue of race is of considerable interest here. The writer of the letter seems to suggest that it is only white women who pose a threat to the fidelity of white men. The author is quite deliberate in specifying that she is referring to the evil of white women 
in the North. Why it is that she excludes aboriginal women from the scope of the contaminating threats to white men's sexual innocence is quite unclear. It would seem that either she believed that aboriginal women and white men did not have sexual relations for whatever reason, or she believed that sexual relations with aboriginal women did not constitute the same kind of transgression as sexual relations with white women. Either way, this letter seems to indicate that sexual relationships between white men and aboriginal women were absent from the purview of concern of those women seeking to cement the bonds of the white family. More absent still is a concern for the well-being of aboriginal families and the sexual integrity of aboriginal women. What is also striking about this letter is the way in which it depicts women as being charged with full responsibility for male sexuality. Male sexuality is seen as a constant and involuntary variable akin to a powerful and dangerous force of nature. All responsibility for this force seems to rest with women. It appears to be entirely the women's job to engage in the enterprise of good management of male sexuality directing it into the white nuclear family. Bad women by contrast are seen as diverting the force out of its manageable confines and thereby letting it loose to wreak havoc. What is interesting here is the reversal of the unusual equation of nature with woman and culture with man. Here rather, we see women understanding their own project as imposition of culture on man's natural sex.

Racialized women bore the greatest brunt of retributive judgment when white male sexuality was seen to have been mismanaged. Another letter, again written by a distressed woman, demonstrates the way in which a racialized woman could be subject to harsher condemnation and coercive invasion for the supposed sexual corruption of an innocent white man. The following letter has a notation at the top of the page which appears to be in Emily Murphy's handwriting and which reads: "Copy taken and handed to the City Det. Dept. for Prompt attention and necessary action."14

\section{Edmonton}

Nov. 8, 1922

Magistrate Murphy

I am laying a matter before you that is quite interesting and will stand a rigid investigation. There is at this No. 10907 - 97 St. a negress name Ethel Croslin. Who has the front of this no. rented and are keeping immorality going on. She have a negress there who have left her husband. name is Pearl Sneed and is running around with a young man (by name Edgar Lewis) are living as man and wife and are not married. they are from Campsie to Westlock and to Spruce Grove. They have been working for lawyer Morrow at Spruce Grove where they lived as man and wife. They are to leave town Fri morning for Cherhill back to Campsie. Her children are at .... with her mother. she is a bad caractor and should be taken up and investigation made and they made to prove they are married. We don't like to see such for the sake of our sons and husbands.

A close neibor 
Investigate if they are gone to bed will prove the facks. is $^{2}$

How Murphy could have thought that this "tip"16 warranted investigation is entirely unclear. Again, a legal foundation for Murphy's invasive actions seems to be utterly lacking.

Murphy's sanctimonious failure of compassion for women who did not measure up to her standards of stalwart control and conformity to middle class expectations is revealed further in an exchange with an Alberta woman named Virginia Clin. The situation here appears to have been that Ms. Clin wrote to Murphy to complain about her treatment in Ponoka hospital. It also appears to have been the case that Ms. Clin had some considerable savings that she had hoped would provide her with the means to live once she got out of the hospital. These savings appear to have been devoured by an account rendered by the hospital to cover her stay there. One can imagine the disappointment, frustration, and alienation Ms. Clin must have felt upon receiving the following letter from Emily Murphy.

Miss V. Clin.

Halkirk, Alberta

My dear Miss Clin:

I have your letter of the 16th of February. It is indeed regrettable that you have had to pay out your savings on account of ill health, for I am sure you have been a thrifty, hard-working girl to have saved the amount of money you mention. Still we are all subject to a like misfortune, none of us being immune from sickness.

According to your letter, you were in the hospital for about 1600 days, and during that time paid out $\$ 917.00$ which sum included your transportation, board, laundry, food, medical attention etc. The hospital charges $\$ 1.00$ a day apart from transportation, so you see the total account would be $\$ 1600.00$, and that the hospital stood to lose approximately $\$ 700.00$ on your illness.

I may say that $\$ 1.00$ a day only pays for the actual expenses of the patient, and does not cover the costs of staff, buildings, and upkeep. These are all borne by the tax-payers of Alberta.

I would like to point out too, that if you had remained ill for the rest of your life, the hospital would have kept you without any remuneration whatsoever. When you come to think it over like this, you will, I am sure, agree that you have not been looking at it properly.

After all, apart from the financial end of the question, you owe a debt to the hospital that money could never repay, in that they restored you to sanity again. Never forget that.

If I were you, I would forget any grievance which you feel you may have, because if you brood on it, you may become insane again. Don't let yourself think for a moment that you were held 
improperly, for the Government is only too glad to get rid of their patients upon whom they are losing money.

Think kind, helpful thoughts like a good girl, and I am sure all will be well with you. You say you were a friend of Irene Lewis. Poor Irene was not so fortunate as you, for you know she died in one of her spasms. Esther Lewis is home again and doing well.

I am glad you wrote to me, and hope this letter will straighten out your difficulty.

Yours very truly,

E.F.M. ${ }^{17}$

In a difficult but fascinating response, Clin meets Murphy's supercilious and condescending advice with a wild, courageous, and far more powerful eloquence. Through her madness, Clin's wisdom and sincerity emerges and ultimately she clearly has the better of the debate with Mrs. Murphy. I have attempted to transcribe the letter here though errors may be present. Clin's script is elegant, even, and refined yet at times it is difficult to decipher as her thoughts do not conform to one's expectations and thus, ellipses cannot be filled with confidence.

Halkirk 22 February 1921

Mrs. E. Murphy

Received your letter tonight: also had the one from the Attorney General the day after I wrote you. You don't know me but am sure Mrs. Murphy you appreciated my feeling. I am sorry to say you know Ponoka Insane Asylum and I get you acquainted a little more.

Like you I say is too bad that sometimes we have to bare ill health. But to stand a hell of 1200 days where you are force to work the second months you are there, been a Hospital it the limit.

Mrs. Murphy if you give me the credit of being good hard working girl why in such a case a girl would have to work there at all? Where she as her way clear, and don't forget the cash was with me. Why did they collect more? 117.00 cash when turn down for a dime wishing for an orange. There is the answered I got. Dr. MacCullough Never a darn cent.

Speaking of work we working class are baring it while these also keep it only personally with you but Mrs. Murphy why not make order? I have seen it where they have the very worst kind they soon let loose and let go back to their same proposition, encourage in it you may say. They know of it on both sides. I suppose they never ever had a cent for their board.

I was refused leave on the 12 of December 1923 and I sent to the nurses home instead with a bad cold and pain in my right lung. Where is the doctor? Before that I was only keep to help for the bazaar and was made to sew on Sunday even the bazaar was on the 8. Coming back to the ward some time in February all I got was suffer it all. More doctor care. 
Don't you know with little care a person soon get better but from the start to the finish there was none. I was so poorly physically when I left there not fit to work anyway. Not that I was incurable but neglected only. I was put in trouble having only a dollar cash with me and truth remain to be truth always. I have live to prove it Mrs. Murphy proving innocent. I was to the bed and a man was let in all undress. God is the strength to the one who are afflicted and always the best of Friend and never you are alone.

I am sorry to have to contradict you but no man living could cure insanity. If you are acquainted of some one, I be please to be acquainted also. You are very much against all things When God Himself give and take away. He is the only healer. In many way as human could help the one who are suffering even mentally. Mrs. Murphy what kind of food giving there.

Long as I live I never forget the supper we had where you folks call there the fall 1925. It was all prepared but really it was good supper. Now take thing at nature if you eat poor food your stomach have the whole control of your body you're bound to come down after while. It also give you headache. Headache are caused by the stomach mostly. How do you like to have rhubarb without sugar, two or three radish or couple leaf of lettuce cut up weeks before that - day after day. Experience was my teacher. Why keeping people there when other offer to see for them. My own money was giving me better than that right at first. My own brother came to take me home 10 days after I first was sent there. They laugh of my suffering. Some doctor they are. You know Dr. Cook went to Calgary fall 1925 and spoke on giving eggs and milk also treat them according to their sickness. Eggs were 10 cents a dozen summer 1924 and never once we ever see away neither before that either. The above was served.

Do you know by taking care properly they would only have half there. They are over keep for one thing and like you telling me if I brood over it I brake down and become insane again. I never made a God of money and only saved it for necessary like sickness and old age. What do I have been keep three years in my young life and tum out at the age of thirty five. It was a saving of ten years. I was working at thirteen. So I owe you educated people a great thank.

I asked while there to be move at jail were it the proper way to punish people and they had say it was to teach me a lesson.

So I hope you consider that I didn't ask nothing in the way and if I refuse a job while there they didn't need to keep me as a patient. I believed the public respect human too much to ever leave those who are left behind me and I hope you be the first one to think of them.

Dr. Cook is highly call the chief criminal by the staff.

A citizen of Alberta I am and not do I wish for the money but truthfully expect Alberta to give little better service.

Virginia Clin. ${ }^{18}$ 
The beauty of Virginia Clin's fragmented expression and the sadness of her story are moving. I can only wonder what Murphy's response was to this letter, whether she felt any twinge of genuine affinity for this woman's situation or whether she would have completely cut herself off and insulated herself from the risks of extending her moral imagination into the insight and pain of this woman. From what they have left for us to understand them by, it would seem that the scattered, poignant, authentic, and poetic world of Virginia Clin was thoroughly and altogether uninhabitable for Emily Murphy.

\section{LATE TWENTIETH CENTURY FEMINIST THEORY: A SCRAPBOOK OF THE STRUGGLE AGAINST UNIVERSALISM}

As I suggested at the outset, the ruthlessness of Murphy's practice as a magistrate bespeaks a theoretical failure linked to the concepts of universalism and essentialism. In the preceding section I have attempted to show the failures of compassion and the moral irresponsibility that Murphy's essentialist understanding of the notion of woman and her confidence in universalizing her own perspective gave rise to. I now want to go on, to examine in some more theoretical detail, the way in which feminism has, in the latter part of this century sought to expose the flaws of universalism and essentialism in order to get past the moral mistakes that are typified by Murphy's exercise of legal power.

In the next part of this article I would like to show some quick glimpses at some of the feminist theorists who have influenced and continue to influence feminist thinking in the Faculty of Law the University of Alberta in the 1990s. To begin this discussion I would say that, broadly speaking, we can understand the project of most feminist theorists as an attempt to reject, transcend, and to surpass the theoretical imperatives of universalism and essentialism. Early twentieth century feminists such as Emily Murphy would, most certainly, not have viewed essentialism or universalism as theoretical problems requiring resolution before a truly equitable praxis of women's exercise of legal power could be realized. However, it is clear that Murphy's insensitivity to issues of difference - issues that undermine the stability of universalism and essentialism - stand behind the failures of moral imagination evident in her papers. Feminist theorists of the late twentieth century have, to their credit, struggled to eliminate universalism and essentialism from their theoretical foundations so that their practice would reflect a greater understanding of and respect for difference. The late twentieth century project in feminism has been not only to develop a nonessentialist understanding of gender difference but also to develop a non-essentialist understanding of difference between and among women.

To explain in more detail what I mean by "universalism" and "essentialism" I will briefly refer to the work of Charles Fried's theory of contractual obligation as a simple example that illustrates some of the methodological imperatives of universalist and essentialist theorizing to which feminist theory is in opposition. This brief sketch of his 
theory will, I hope, provide a necessary foil to enhance my explanation of what it is that feminists have been attempting to achieve in their critique of this method. ${ }^{19}$

Fried's theory (which is nominally a theory of contract but which can be more broadly understood as a theory of law and government) begins with an attempt to answer the question "what distinguishes mankind?" In this, his theory is both universalist and essentialist. He purports to discover qualities that are essential to human beings and that are held by all human beings universally. In this tradition of political theorizing the task of describing the essential universal characteristics of "man" as distinct from animals has a central role. ${ }^{20}$ Once it is discovered, or created, this quality acts as a first premise in an argument that concludes with the moral justification of a set of corresponding universal rights or entitlements that legitimate governments will afford to all individuals."

Much of western political theory, from which feminism seeks to distinguish itself, proceeds by way of this method. The theorist first narrates of the nature of man according to his own experience and observation and proceeds from there to argue for a particular set of political and legal entitlements which are said to flow as a matter of both logic and morality from this - mankind's nature - as the theorist has constructed it. The universal nature of mankind is the foundation from which entitlements are derived and this nature further determines the content of what it is that governments must do to earn legitimacy.

The essential quality that Fried attributes universally to mankind is an autonomy which is fundamentally exploitative - in the broadest sense of that word - and an indomitable will to expansion. Fried writes:

Everything must be available to us, for who can deny the human will the title to expand even into the remotest comer of the universe? And when we forbear to bend some extemal object to our use because of its natural preciousness we use it still, for it is to our judgment of its value that we respond, our own conception of the good that we pursue. ${ }^{22}$

Thus, the theory argues that what is essential and salient about human beings is our autonomy (conceived as a capacity and desire to bend the external to our use). The first premise of the theory - the one that posits an essential and salient human quality is and must be cast in terms of universals. So, Fried speaks about "us," "we," "the human will." ${ }^{23}$ This rhetoric of inclusion is necessary because it facilitates the simultaneous inclusion and exclusion of those who are covertly identified as different. By including everyone, the theory stakes out a claim of not just universalism but

19 C. Fried, Contract as Promise: A Theory of Contractual Obligation (Cambridge: Harvard University Press, 1981).

20 See e.g. R. Nozick, Anarchy, State, and Utopia (Oxford: Basil Blackwell, 1974 ) 35.

21 It is also the first premise in a parallel and symmetrical but subtextual argument that concludes with moral absolution for the exclusion and use of anything that is understood as lacking the discovered/created quality.

$22 \quad$ Supra note 19 at 8.

$23 \quad$ Ibid. 
egalitarianism. However, the basic feminist concern here is that by excluding many in the actual images it creates, it lays the theoretical groundwork that results in the practical consequence of privileging a few.

Thus, feminists would argue that one of the functions of the language of universality in such a theory is to pacify the excluded by flattering them. The grandeur of the essentialist description of humanity is what makes it potentially sellable to those the theory shortchanges. So, Fried paints a portrait of humanity as inescapably exploitative. It would seem that on his understanding of human nature, there is nothing any of us can do to stop being exploitative. Even when I am lying on the ground looking up at the stars I am engaged in the activity of exploitation because I use those stars both in my decision to enjoy them and in my decision to forbear from putting them to some other use. Further, the quality of exploitation is narrated as a powerful and vital thing. The portrait that Fried of purportedly paints of all of us is so majestic in its empowered autonomy that it is (at least a little bit) difficult to disclaim it.

The middle premise in this argument is that the job of governments is to respect that which is defined as essential to mankind. From here we move quickly to the conclusion which, in Fried's case, is that governments should respect this capacity to exploit, this capacity for empowered autonomy, this ability to order the external world around us. Thus, governments should stay out of the way of the exercise of our desire to expand into all corners of the universe by creating a system of contract law that allows us to construct our private contractual obligations in accordance only with the dictates of our autonomous will, mediated by the requirement for consent of others whose assistance we desire in the carrying out of our autonomous projects. In other words, the government's job is to leave "us" to it. So, Fried's narration of the quality of the human will is in aid of a laissez-faire theory of contract and, more broadly, a theory of the minimal state. ${ }^{24}$ The fundamental point that feminists and other critical theorists seek to make however, is that the entitlement to unfettered freedom turns out to be far more useful to those who bear the most likeness to Fried's portrait of "Mankind" - that is those who have power and property - than it is to women, minorities and the dispossessed.

I think it is useful to look at Fried here simply in order to get a sense of (or perhaps in this hasty rendition only a caricature of the theoretical orthodoxy which feminist theorists reject. Feminists have argued that universalist theorizing operates to the benefit of those persons who have had the power to define what is essential and universal on the basis of their own particular experience without recognizing the partiality of their position. The reason that feminists have rejected universalism is primarily because the definitions of humanity embedded in them have been seen to be inherently male. What feminist theorists have sought to expose is that universalism does not describe or reflect 
women's experience and that it does not result in a political practice that respects women's interests or values their participation.

The vast majority of feminist theorists would most likely agree that because universalism either covertly or overtly excludes the experience and existential reality of women it is unacceptable as a method of theorizing. ${ }^{25}$ There is less agreement, however, on how feminism can actually accomplish the goal of ridding itself of the faults of universalism and what theoretical method should replace the familiar universalist syllogism.

What I would like to do now, is to provide a quick look at a few attempts by feminist theorists to oppose and transcend universalism. Each of the theorists who I will discuss has been influential in the feminist community in the Faculty of Law at the University of Alberta. ${ }^{26}$ While we may think of these theorists as being in opposition to each other - it is nevertheless true that they can each also be seen as contributing clues leading us closer and closer to cracking the universalist code. ${ }^{27}$

One way that feminists have opposed this universalist method is by painting a portrait of women that brings into the foreground the exclusionary backdrop of the male universalism. In other words, feminists have attempted to critically expose the ways in which men have constructed women as different from and inferior to men and have thereby justified their exclusion. This endeavour was very much part of the project of radical feminists like Catherine MacKinnon and Andrea Dworkin who were very influential in setting the tone of gender discussion in law schools in North America including the University of Alberta in the early and mid eighties. Radical feminism attempted to push male universalism to a moment of crisis and to force it to recognize the fraudulence of its own claim that it was meaning to include everyone in its universalist descriptions. Focusing its critique on sexuality and the drive to dominate that was seen to be inherent in men's experience of sexual desire for women, radical feminism exposed the ways in which male theory actually depicted women as naturally inferior to men while it claimed to depict all people as equal. Radical feminism identified sexual assault, sexual harassment, domestic violence, and pornography as the basic practices through which our male dominated society entrenches and enthrones male sexual hostility and aggression as necessary and desirable background conditions of life. Through the systematic perpetuation of these practices by individual men, and

For much more detailed discussions of these kinds of criticisms of universalist political theory see C. Pateman, The Disorder of Women (Oxford: Oxford University Press, 1989); Shanley \& Pateman, Feminist Interpretations and Political Theory (Oxford: Polity Press, 1991); I.M. Young, Throwing Like $a$ Girl and Other Essays in Feminist Philosophy and Social Theory (Bloomington: Indiana University Press, 1990); I.M. Young, Justice and the Politics of Difference (Princeton: Princeton University Press, 1990).

2s C. MacKinnon, Feminism Unmodified: discourses on life and law (Cambridge: Harvard University Press, 1987); C. MacKinnon, Toward a Feminist Theory of the State (Cambridge: Harvard University Press, 1989); C. MacKinnon, Onhy Words (Cambridge: Harvard University Press, 1993); A. Dworkin, Intercourse (New York: The Free Press, 1987); A. Dworkin, Pornography: men possessing women (New York: Putnam, 1981). 
the collusion in these practices by the law, women's lives were seen to be inexorably dominated by male disdain for and desire for control over women. Thus, Andrea Dworkin writes:

By definition, as the God who does not exist made her, she is intended to have a lesser privacy, a lesser integrity of the body, a lesser sense of self, since her body can be physically occupied and in the occupation taken over. By definition, as the God who does not exist made her, this lesser privacy, this lesser integrity, this lesser self, establishes her lesser significance: not just in the world of social policy but in the world of bare, true, real existence. She is defined by how she is made, that hole, which is synonymous with entry; and intercourse, the act fundamental to existence, has consequences to her being that may be intrinsic, not socially imposed. ${ }^{23}$

So Dworkin depicts women as essentially penetrated, inferior, beast like, slave like, passive, made for violation and defilement. The portraits of women that she paints are definitely copies from the works of the patriarchal artists, but they are not exact copies because they are transformed by the anger that is infused into the process of the painting. Women's difference comes from and arises out of the ways in which men have constructed women as different from and inferior to men, and as the same as one another. There is, then a kind of essentialism that derives its meaning from the homogeneity of the fact of women's domination. In other words, men have constructed women as creatures to be used for sexual gratification, reproduction, and domestic labour. The fact of this male assumption of the essence of women gives women a base of common ground with one another that is, at once, both real and artificial. Real because it generates common experiences that have political significance, and artificial because it says nothing about the authentic nature of women's selves or their potential.

While radical feminism was deeply influential in putting the gender question on the agenda in law schools in the 1980s it was subject to serious critique from women who did not experience gender as the most or as the single operating factor in their oppression. Women of colour and lesbian women attacked radical feminists for being guilty of the very error and violation they were attempting to eradicate. ${ }^{29}$ Thus, women of colour quite correctly pointed out that one cannot approach gender on the basis of an uncomplicated assumption that women have all been constructed in the

A. Dworkin, Intercourse (New York: The Free Press, 1987) at 123. The book, as a whole, is a good example of what I am trying to convey here. Much of the book draws on examples of fiction written by men that reveal the male view of women as loathsome objects useful for sexual gratification. Indeed, at a number of junctures Dworkin weaves in and out of her own voice, laced with anger and irony, and the voice of the male novelist. For example, she writes as follows, (ibid. at 16-17 intermittently quoting from L. Tolstoy, in "The Kreutzer Sonata" in Great Short Works of Leo Tolstoy, trans. L. Mande \& A. Maude (New York: Perennial Library, 1967):

Marriage through sexual attraction, that is , so-called love, is also an institution of inequality because of what women must do to attract husbands: the woman is "a slave in a bazaar or the bait in a trap." Because she is "a means of enjoyment" she will always be used as such, and her inferiority will be created and maintained through that usage of her for enjoyment. 
same way by men. Women of colour and lesbian women have challenged radical feminism by highlighting other characteristics of women which have been identified by men as relevant, as having political significance and as justifying different kinds of exclusion and oppression. The manner of male objectification of women has not been homogenous. Thus radical feminism has been attacked on the basis that it ignores the significance of the variation and nuance of men's oppression of women.

One extremely eloquent example of the force of this critique was put forward by Patricia Monture, a First Nations woman, whose formidable rhetorical skill and strength provoked and inspired an increase in the sophistication and nuance in discussion in feminist circles in Canadian law schools. One aspect of Monture's critique of white radical feminism proceeds by first noting that white feminists are clearly correct in arguing that white men in positions of power have constructed white women as creatures inevitably and naturally tied to the project of reproduction and child rearing. Further, it is true that from there men seemingly concluded it was justifiable and desirable to use their power to keep women in that role. However, what is not accurate in the radical feminist account is the assumption that all women were constructed that way or that they all experienced the oppression of white male power as coercing a life of domesticity. The obvious and yet erased contrast Monture draws our attention to is that white men in positions of power viewed First Nations women as utterly incompetent as mothers and incapable of responsible child rearing. It was therefore, seen as justifiable and desirable to use white male power to take children away from First Nations mothers. ${ }^{30}$ Thus, for First Nations women the project of liberation was not to been escape from the mothering role but rather to reclaim an entitlement to it. This critique seems to make it abundantly clear that feminism cannot proceed on the basis of an assumption that the nature of all women's oppression and the substance of their difference as women is the same.

Some feminists however, have persisted even in the face of the critique of feminism by women of colour, cultural minority women and lesbian women in attempting to make broad and universally applicable generalizations about women that act as the foundation of their arguments about the appropriate response of the law to the issue of gender. Robin West, another influential feminist legal theorist, has departed from radical feminism in the sense that she does not focus on men's degrading images of women. However, an examination of her innovative and influential article "Jurisprudence and Gender"131 reveals that West does aspire to a political and legal theory based on the idea that women do have essential characteristic significantly different from those of men. Thus, West follows the process of making generalizations about all women that she takes to be true and then arguing from these generalizations that different entitlements flow from the different essential attributes of women.

In generalizing about women's nature West argues that women are essentially materially connected to others. She writes: 
[W]omen are in some sense connected to life and to other human beings during at least four recurrent and critical material experiences: the experience of pregnancy itself; the invasive and "connecting" experience of heterosexual penetration, which may lead to pregnancy; the monthly experience of menstruation, which represents the potential from pregnancy; and the post pregnancy experience of breast-feeding. ${ }^{32}$

She argues that it is the job of governments and the law to begin to respect that connectedness. Thus West, to some degree, adopts the method of male universalism in that she seeks to identify a defining characteristic of women that grounds the basic obligations of the state. She seeks to do this in a universalist and essentialist way in that she puts her generalizations about women's existential condition forward as true, real, and applicable to all women. From this premise she goes on to argue that different rules and entitlements flow from the different attributes of women's essential nature. This method does not really abandon the basic imperatives of Fried's methodology except in so far as it initially requires the recognition of at least a position of difference. ${ }^{33}$ Indeed, West begins with an express statement that she is playing by familiar rules of identifying what is important and distinctive about people and then moving to a conclusion about what the nature of the state should be. She begins "Jurisprudence and Gender" with the following statement: "What is a human being? Legal theorists must, perforce, answer this question: jurisprudence, after all, is about human beings. ${ }^{134}$

Having accepted the framework of male political theory West then goes on to argue that within male political and legal theory the thing that is defined as being central to humanity - is separateness. What is important about human beings is that we have an existence that is separate and distinct and cut off from objects around us - we have distinct boundaries. West argues that this separation thesis is patently untrue for women and that women have an essential potential for physical, material connection to other people and that this potential for connection is definitive of their existential state. She paints the portrait of women as physically connected to other human beings in the material experiences of menstruation, lactation, heterosexual intercourse and pregnancy. It is interesting to note here that in defining women's essential characteristics West does not distinguish women from animals when she narrates women as essentially materially connected. Rather, she defines women in terms of their animal characteristics. All female placental mammals have potential for connection in the same material way that West has identified in women.

Of course, if West were correct in her interpretation of male political theory - that it posits separateness as what defines and signifies the importance of being human, then indeed, that theory would also have failed in identifying any special feature that distinguishes human beings (men) from animals. Men defined by their separateness

Ibid. at 1-2.

I will note below that West concludes by abandoning that initial commitment to the recognition of difference in that she assumes that a reorganization of social institutions, in particular the family would eliminate difference and make way for a humanist jurisprudence.

Supra note 29 at 1. 
would, in fact, be even worse off on this score because men would share their essential defining characteristics not only with male mammals but also with reptiles, amphibians, and even rocks - for all of whom the separation thesis is true. In fact, however, liberal theory does not define physical separateness as the significant characteristic for "men." Rather, it identifies the capacity for autonomy, choice, rational decision making, rule making, principled judgment to be the characteristics of human beings that entitle them to some kind of particular treatment. ${ }^{35}$ Such a capacity may assume a weak version of the separation thesis but this weak version is not "patently untrue of women."

Although West opposes universalism, it would seem that West's method must ultimately lead to a conclusion of two different and parallel universalist political/legal theories, one that applies to men and one that applies to women. If one accepts West's construction of the difference between men and women, the upshot must be that in relation to men who are separate and whose humanity is manifested in their capacity for autonomy, governments must respect autonomy and in relation to women who are connected and whose humanity is manifested in their capacity for intimacy governments must respect that intimacy. West, however, wants to resist this conclusion. It is at this point that West begins to back-peddle on her initial position that affirmed a politically significant material difference between men and women. In the final analysis, West reveals herself as deeply committed to a thorough going universalism and a humanist jurisprudence.

To get there she returns to the physical difference between men and women that she initially identified. She notes, at this point, that the connection thesis is not always true of women. Likewise, the separation thesis is not always true of men. Women have capacity for autonomy in the same sense that men have a capacity for intimacy. In establishing that this is potentially physically true of men she writes:

The "separation thesis " as I have argued, is drastically untrue of women. What's worth noting by way of conclusion is that it is not entirely true of men either. First, it is not true materially. Men are connected to another human life prior to the cutting of the umbilical cord. Furthermore, men are somewhat connected to women during intercourse, and men have openings that can be sexually penetrated. $^{36}$

See e.g. supra note 20 at $48-49$ where Nozick demonstrates this aspect of the focus on rationality and capacity for choice by describing the defining characteristics of man in the following way:

[A] being able to formulate long-term plans for its life, able to consider and decide on the basis of abstract principles or considerations it formulates to itself and hence not merely the plaything of immediate stimuli, a being that limits its own behaviour in accordance with some principles or picture it has of what an appropriate life is for itself and others ... the ability to regulate and guide its life in accordance with some overall conception it chooses to accept.

Supra note 31 at 70 [emphasis added]. It is hard to know how West would argue out the point that the separation thesis is drastically untrue of women while admitting that the connection thesis can be untrue of women. It would seem that she must be envisaging some middle ground in which a woman is not connected to other human life and is still not separate. 
There are a number of difficulties with this passage. First, West claims to be focusing on men's physical connection to other human life in this discussion. But if we are really focusing on the material aspects of the connection how can it be that men are in any sense less physically connected than women? How can it be that the mother is somehow more connected to the male foetus than he is to her or that the mother who breast feeds a baby is more physically connected to that baby than the baby is to her. Or that the woman is more physically connected to the man in intercourse than he is to her? Why would it be the case that men's final unalloyed capacity for connection is in their vulnerability to be penetrated by a penis? All of this seems to ignore or to equivocate on the meaning of material connection. Material connection, it would seem, is either a loss of physical boundaries or a condition in which boundaries are stuck together. If we take this to be true then it is difficult to understand how "females" are more physically connected than "males", in either heterosexual intercourse or in pregnancy or lactation where foetus or child are male.

It seems, however, that if West wants to insist on a differentiation in the degree of connection between males and females that she must be referring to a varying degree in the extent to which males and females experience physical connection as intimacy. The point must be that women feel the physical connection differently than men do. They understand the physical connection as human intimacy where as men (and possibly foetuses and babies) do not. Women experience pregnancy and lactation as conscious, thinking separate agents. They are therefore able to give meaning to that physical connection and endow it with moral and emotional significance. The question of what its moral and emotional significance is or should be is not predetermined by the fact that it is a physical connection with another human being.

Having established the possibility of the physical condition of connectedness in men and the possibility of a physical condition of no connectedness in women, West goes on to argue for the possibility of intimacy as a value for men and autonomy as a value for women. West refers to the work of a number of feminists who argue that gender difference is not a function of biological difference. ${ }^{37}$ She appears to endorse the view that gender difference is created out of the structure of family relationships and in particular out of the mothering role of women. ${ }^{38}$ Using this as a point of departure, West then attempts to redeem universalism by arguing for a way of making people the same through the elimination of gender. Rather than rejecting the project of universalist political theory, West ends up rejecting difference. She concludes by vaguely sketching a genderless world where men and women have equal capacities for separateness and connection, autonomy and intimacy and then argues that the consequences for government are to respect and protect both that autonomy and that intimacy. Having expressly bought into the traditional method of universalist political theory West cannot maintain a hard line stance on difference. Thus, West's theory provides limited assistance in overcoming the insensitivities that a universalist method gives rise to.

38 For a similar but more fully developed argument see S. Moller Okin, Justice, Gender, and the Family (New York: Basic Books, 1989). 
Another feminist thinker who offers a way out of universalist and essentialist thinking whose writing has been influential at the University of Alberta is Hélène Cixous. Cixous as a poetic writer, constructs an image of women that is strong, different, and beautiful. She writes:

Flying is woman's gesture - flying in language and making it fly. We have all learned the art of flying and its numerous techniques; for centuries we've been able to possess anything only by flying; we've lived in flight, stealing away, finding, when desired, narrow passageways, hidden crossovers... A feminine text cannot fail to be more than subversive. It is volcanic; as it is written it brings about an upheaval of the old property crust, carrier of masculine investments; there's no other way. There's no room for her if she's not a he. If she's a her-she, it's in order to smash everything, to shatter the framework of institutions, to blow up the law, to break up the "truth" with laughter. ${ }^{39}$

Cixous affirms the difference of women and self-consciously both describes it and creates it. She narrates the possibilities of woman, she offers ways for women to interpret themselves and their experiences that are empowering, invigorating and indeed flattering. She speaks of women as volcanic. She writes: "Her libido is cosmic, just as her unconscious is world wide.... Her language does not contain, it carries; it does not hold back, it makes possible. ${ }^{40}$ "[S]he is everywhere, she exchanges she is the desire that gives." ${ }^{.41}$

Cixous's writing is full of hubris. Cixous's description of women is buoyant and omniscient ascribing to women an enormous capacity to create, to feel, and to give. In narrating women's strength, her passion and her possibility Cixous is never reductionist. She is never essentialist in the sense of trying to find a lowest common denominator of women. She understands and affirms the infinite variety of women. And yet paints a likeness that liberates, that resonates within, that flatters but does not constrain, reduce or homogenize. Rather than playing the taxonomist who classifies, pins, and boxes women up according to their similarities, Cixous plays the true friend, who pulls at something inside of women in an effort to get them to create themselves.

Cixous begins "The Laugh of the Medusa" speaking about her refusal to allow the past to determine the future. She says "Anticipation is imperative." 42 This is another statement that is filled with hubris and, sadly, I think, it is also wrong. It assumes a control that we do not always have. Women are often simply unable to free themselves and protect themselves from the violence of individual men and of male institutions. We just do not always have the power to make anticipation imperative. At the same time, the statement is also right. If women understand themselves in terms of their strengths, if they interpret their experiences in recognition of their strengths then, they are more likely to grow into a realization, acknowledgement and celebration of that strength rather than an embarrassed victimized morbid denial of it. This sense of one's

H. Cixous, "The Laugh of the Medusa" in Marks and de Courtivron New French Feminisms (New York: Schocken Books, 1981) at 258.

Ibid. at 259-60.

Ibid. at 263.

Ibid. at 245. 
own strength along with a sense of one's own difference is, indeed, deeply subversive. This is not to say that oppression can be narrated away. But it is to say that our understanding of ourselves shapes the way in which we approach our struggles.

It is, of course no more true to say that woman's libido is cosmic than it is to say that it is impossible to deny man the title to expand into the remotest corner of the universe. However, Cixous's extravagance in her portraiture of women is life affirming and empowering. Her writing abandons the project of ordering and does not use her descriptions of women as justification for any system of rules or principles. Her uncompromising celebration of difference seems to require a reexamination of the relationship between rules, justice and consistency. Her hubris does not have an insidious quality because its project is to empower and to inspire to creativity rather than to construct and impose an order on the world. Her insistence on the significance of difference requires that we abandon the rule making project altogether. Thus, Cixous embraces the apprehensive accusation that women are forces of disorder.

\section{CONCLUSION}

Through these few examples of the ways in which late twentieth century feminists have attempted to create theory that transcends the universalist method that purportedly gives rise to exclusionary practice demonstrated by the letters of Emily Murphy we can see the difficulty of escaping universalist theory as well as the multiplicity and diversity of attempts to transcend it. While these are incomplete and fragmented looks at the feminist project now and then, they show us that the project of women's attempts to transcend and transform the exclusionary aspects of male institutions has a long and interesting history. From beginning to end it is as full of moments of progress and insight as it is full of moments of failure and neglect of those things that should ultimately matter. As an equality seeking movement, feminism continues to struggle to live up to its own standards of inclusiveness and concern for persons struggling on the margins of society to come into a place of authentic voice. Perhaps one thing that can be taken from this look at both the feminist practice of Emily Murphy and the feminist theory of the late twentieth century is that feminist failures to create meaningful exchange across lines of difference do not erase feminist successes in the same project. Neither Murphy's, MacKinnon's, Dworkin's, Monture's, West's nor Cixous' work can be conscionably dismissed or discounted. Nor should failures be papered over. The obvious difficulty of working successfully through the project of coming to terms with difference gives us reason to be charitable with those who have contributed to its advancement - irrespective of their shortcomings. Indeed, the clarity of the picture of Emily Murphy's high-handedness reminds us of how easy it is to act at cross purposes to our goals even as we passionately espouse them. 